\title{
POLITICAL RESPONSES TO THE EXTREME RIGHT IN POLAND. MOTIVATIONS AND CONSTRAINTS
} FOR COLLABORATION IN THE EXECUTIVE ARENA

\begin{abstract}
The aim of the article is to indicate potential causes for formation of a government coalition with the extreme right-wing League of Polish Families (LPR) in Poland in 2006. The aim is to determine the motivation of the right-wing mainstream Law and Justice party to cooperate with LPR, but also to indicate potential reasons why the coalition was not concluded until nine months after the elections. The goal is therefore to highlight potential constraints in the formation of the coalition. The analysis uses theories of coalition formation based on the rational choice paradigm (office, policy and vote) combined with an empirical approach to coalition research, with particular emphasis on factors such as the structure of competition in the party system and the internal dynamics of parties. The starting point for this analysis is the result of research on the causes of cabinet collaboration with the extreme right in Western Europe. The aim is to indicate whether the motivations for forming a coalition with the extreme right in Poland are based on similar premises and mechanisms. The analysis combines the deductive approach resulting from the theory of coalition formation with the inductive analysis of facts and factors that accompanied the formation of the coalition. In order to achieve the assumed goals, the article uses quantitative and qualitative methods and systemic analysis.
\end{abstract}

Keywords: extreme right, cabinet coalitions, party strategies, motivations, constraints. 


\section{INTRODUCTION}

Electoral successes in the last few decades have given populist parties on the extreme right the opportunity to take up seats in the parliaments of many European countries, forcing the parties of the mainstream to declare their positions on their extreme-right counterparts. ${ }^{1}$ Mainstream parties may adopt various strategies, including either isolating or cooperating with extreme parties, such as by creating cabinet coalitions. ${ }^{2}$ For decades, extreme right-wing parties were treated as political pariahs and excluded from potential government coalitions, and frequently frozen out in the parliamentary and electoral arenas. Researchers believed that such coalitions were impossible, describing them as unavailable coalitions. They explained this phenomenon mainly by normative obligations derived from the experiences of World War II. Citing the lack of acceptance of the ideology and values offered by extreme right-wing parties as well as the need to protect democracy, many researchers still believed in the 1990s that such parties would be isolated. ${ }^{3}$ Nevertheless, since then the extreme right has entered the governments of many countries in Western and Eastern Europe. Examples of co-operation go back to the early 1990s when Italy's Silvio Berlusconi invited the far-right parties National Alliance (Alleanza Nationale) and Northern League (Lega Nord) to join the government initiated by Forza Italia in 1994. In Slovakia, the Slovak National Party (Slovenská Národná Strana) assumed office in 1992 and 1994. The same happened in Romania, where the Greater Romania Party (Partidul România Mare) and Romanian

\footnotetext{
1 Despite the various conceptualizations appearing in the literature, the terms extreme right, far-right and radical right will be used interchangeably in this paper. It means the parties located at the furthest right end of the left-right axis in a given party system, which are characterized by a specific catalog of universal features, including opposing to the principles and/or values of liberal democracies (though to varying degrees), nationalism (mostly based on culture), traditional morality, combining the slogans of neoliberalism and state protectionism. Usually they are accompanied by populism understood as an opposition towards political elites and all non-belonging to the specifically defined 'community' (ethnic or cultural).

2 According to William M. Downs, political actors may choose between the strategies of engagement or disengagement. Each strategy contains a wealth of options that bring with them diverse benefits and risks. An engaged attitude may be expressed in the co-opting of policies of extremist parties and/or cooperation with them in the electoral, parliamentary and governmental arena. Disengagement strategies may appear in the form of ignoring extreme parties or putting legal restrictions on them. W.M. Downs, Pariahs in their Midst: Belgian and Norwegian Parties React to Extremist Threats, "West European Politics" 2001, Vol. 24, Issue 3, pp. 24-28.

3 K.A. Twist, The Mainstream Right, the Far Right, and Coalition Formation in Western Europe, A dissertation University of California, Berkeley 2015, p. 9.
} 
National Unity Party (Partidul Unității Naționale a Românilor) briefly governed in the first half of the 1990s. At the beginning of the twenty-first century, there has been an intensification of far-right parties participation in governments in both parts of Europe, such as, for example, government coalitions in Austria (2000-2005), the Netherlands (2002-2003), Italy (2001-2006, 2008-2011), Slovakia (2006-2010, 2016-present), Poland (2006-2007), Latvia (2011-2014), Norway (2013-present). In many countries extreme right parties also supported minority governments - Denmark (2001-2005, 2005-2007, 2007-2009), Norway (2001-2005) and the Netherlands (2010-2012). ${ }^{4}$

The theory of coalition formation based on the paradigm of rational choice, combined with an empirical approach to research into coalitions, has been helpful in defining the reasons for cabinet cooperation with the extreme right in Western Europe. Research has shown that extreme right-wing coalitions are the result of strategic calculations of right-wing mainstream parties based on a profit and loss analysis that often takes precedence over normative considerations. The increase in support for extreme parties has created both new coalition alternatives for the moderate right and serious electoral competition. This has rationalised the policy of the mainstream parties and led them to abandon isolationist policies in favour of cooperation with the extreme right. Ideological objections lost their importance in the face of new opportunities for strategic goals such as government formation and political influence. Research has also shown that relations with the extreme right are the result of changing patterns of rivalry and cooperation between parties in the party system. ${ }^{5}$

The patterns in Western Europe described above have not yet been systematically verified by studies of coalitions with the extreme right in Central and Eastern Europe. Due to the different patterns of

4 M. Minkenberg, Profiles, Patterns, Processes: Studying the Eastern European Radical Right in its Political Environment, in: M. Minkenberg (ed.), Transforming the Transformation? The East European Radical Right in the Political Process, New York 2015, p. 36; K.A. Twist, op. cit., p. 6; S.L. De Lange, Radical Right - Wing Populist Parties in Office - A Cross National Comparison, in: U. Backes, P. Moreau (eds), The Extreme Right in Europe: Current Trends and Perspectives, Göttingen 2011, p. 192.

5 T. Bale, Cinderella and Her Ugly Sisters: the Mainstream and Extreme Right in Europe's Bipolarizing Party Systems, "West European Politics" 2003, Vol. 26, Issue 3, 67-90; S.L. De Lange, From Pariah to Power: The Government Participation of Radical Right-Wing Populist Parties in West European Democracies, Antwerp 2008; K.A. Twist, op. cit.; D. Albertazzi, S. Mueller, Populism and Liberal Democracy: Populists in Government in Austria, Italy, Poland and Switzerland, "Government and Opposition" 2013, Vol. 48, Special Issue 03, pp. 343-371. 
competition and inter-party cooperation in both parts of Europe and the ideological specificity of political parties in the post-communist countries, it seems interesting to ask whether coalitions with the extreme right in Eastern Europe are based on similar processes and factors that have been shown in Western Europe. What other factors, specific to a given country or region, could have influenced the formation of such coalitions?

This article's purpose is to define the potential causes of the formation of a coalition government with the extreme right party in Poland in 2006. The coalition was formed between the national conservative party Law and Justice (PiS), the agrarian-populist Self-Defence of the Republic of Poland and extreme-right and populist League of Polish Families (LPR). The objective of the article is to indicate whether this coalition can be explained by the rational choice approach which concerns office, policy and vote-seeking behaviour of the mainstream right party. The aim is also to examine what other factors at the system and party level, particularly internal party dynamics and the structure of rivalry in the party system, led to the formation of this coalition? From a different perspective, the aim is also to reveal potential constraints to this coalition, as it was built nine months after elections. ${ }^{6}$ This particular case seems to be especially interesting, as the entry of the extreme right into government was a gradual process. Numerous events like unsuccessful coalition talks between PiS and the right-wing liberal Civic Platform (PO), and a failed minority government of PiS supported by SRP and LPR preceded it. This would indicate the complexity involved in the process of forming a coalition with the extreme right in Poland, allowing us to examine the strategic calculations made by political parties.

The analysis will also enable determination of whether the causes for the formation of coalitions with the extreme right identified in Western Europe are applicable to different party systems, which would strengthen their explanatory capacity. It will also explain unique factors in the given case. The conclusions may serve as a starting point for investigation into the causes of the formation of coalitions between the moderate and extreme right in other Central and Eastern European countries.

The analysis combines the deductive approach that follows from coalition formation theories with an inductive analysis of the facts

6 The formal coalition agreement was signed in May 2006 and lasted 14 months (until August 2007). 
and factors that accompanied the formation of this coalition. To achieve these goals, quantitative and qualitative methods are applied in the article, as well as systemic analysis. ${ }^{7}$ Qualitative analysis has been based on both primary (party documents, media content) and secondary literature.

\section{COALITIONS WITH THE EXTREME RIGHT - THEORY AND RESEARCH RESULTS IN WESTERN EUROPE}

Analyses of individual party preferences most often make use of the theory of rational choice, which has generated three models of competitive political party behaviour: office-seeking, policy-seeking and vote-seeking. The first two models (office- and policy-seeking) derive from traditional research into coalitions, and have been adopted as so-called formal theories of the formation of coalitions, based on logical and mathematical calculations. The vote-seeking party model, on the other hand, comes from work on electoral competition. These theories assume that political parties are rational, calculating actors striving to maximise their utility in aspiring to office, promoting policy or gaining votes, or a combination of these objectives. Government participation is one way for them to achieve their goals. However, when parties evaluate potential government participation, they are likely to face trade-offs and prioritize goals. ${ }^{8}$ Thus the extent to which a party values office holding, policy influence and vote maximisation will influence the composition of a coalition government. This especially applies to the prime minister's party, whose preferences weigh heavily on the outcome of the coalition formation process.

Rational choice theories assume that a prime minister's party that attaches more importance to holding office will focus primarily on size-related (legislative weight) junior coalition characteristics. Indeed, the smaller the weight of the coalition partner, the greater the power that remains in the hands of the prime minister's party. On the basis of this assumption, three office-oriented coalition formation

\footnotetext{
This work was supported by the National Science Center (Poland) under Grant number UMO-2014/15/D/HS5/03272. I would like to thank Prof. A. Antoszewski, dr J. Kozierska, and the participants of the ECPR Joint Session, Salamanca 2014 (Workshop: Defending or damaging democracy? The Establishment's reactions to political extremists in liberal democracies), for their inspirational discussions and the reviewers for their useful comments.

8 K.A. Strom, Behavioral Theory of Competitive Political Parties, "American Journal of Political Science" 1990, Vol. 34, Issue 2, pp. 565-573.
} 
theories have been created - the minimal winning, minimum size and bargaining theories (discussed in detail in the next section). ${ }^{9}$ Parties that attach more importance to policy will focus primarily on policy-related party characteristics. A prime minister's party seeking to maximize its influence over policy will select junior coalition members whose policies are relatively close to their own, as policy proximity facilitates compromise. Based on that, two policy-oriented theories have received the most attention - the minimal connected winning and minimal range theories (discussed in detail in the next section). ${ }^{10}$ Finally, a Prime Minister's party that attaches more importance to votes (future electoral ambitions) will focus primarily on electoral changes in the party system (patterns of electoral gains and losses), but also on voter preferences expressed in voting and public opinion polling regarding inter alia coalition preferences. ${ }^{11}$

Coalition-formation theories based on the rational choice models of competitive political party behaviour also assume that there are no other a priori determinants (constraints) exerting an influence on the formation of a coalition. By the same token, they do not take account of factors in the real environment such as institutional, legal or accidental (ad hoc) factors resulting from behavioural norms. On the one hand, this may be considered a weakness of such theories; on the other hand, the isolation of particular determinants from a complicated political ecosystem makes it possible to systematize an analysis of the reasons for entering into a coalition. ${ }^{12}$ By acknowledging the general 'coalitionability' of all political parties, these theories also make it possible to acquire a broader perspective, free of a normative element, which is of particular importance in the case of anti-system parties. This permits a more rational explanation for a government's co-operating with the extreme right at the cabinet level.

\footnotetext{
9 L. Von Neumann, O. Morgenstern, Theory and Games of Economic Behavior, Princeton 1944; W.A. Gamson, A Theory of Coalition Formation, "American Sociological Review" 1961, Vol. 26, Issue 3, pp. 373-382; W.H. Riker, The Theory of Political Coalitions, New Haven CT 1962; M. Leiserson, Coalition Government in Japan, in: S. Groennings, E.W. Kelly, M. Leiserson (eds), The Study of Coalition Behavior: Theoretical Perspectives and Cases from Four Continents, New York 1970, pp. 80-102.

${ }_{10}$ M. Leiserson, Coalitions in Politics: A Theoretical and Empirical Study, $\mathrm{PhD}$ Dissertation, Yale University, New Haven 1966; R. Axelrod, Conflict of Interest: A Theory of Divergent Goals within Applications to Politics, Chicago 1970; A. De Swaan, Coalition Theories and Cabinet Formations: A Study of Formal Theories of Coalition Formation Applied to Nine European Parliaments after 1918, Amsterdam 1973.

${ }_{11}$ K.A Strom, op. cit., pp. 566-568; S.L. De Lange, From Pariah to Power, pp. 44-46.

12 M. Laver, N. Schofield, Multiparty Government. The Politics of Coalition in Europe, Michigan 2007, pp. 195-215.
} 
The mentioned weaknesses of theories based on rational choice have motivated behavioural (empirical) research on coalitions. ${ }^{13}$ This approach indicates the necessity to also account for each country's specific features before meaningful interpretations of the politics of coalition can be developed, as "what is mathematically possible is not necessarily politically realistic."14 This approach takes various factors into account that result from social and political realities which condition the formation and maintenance of coalitions. These include the mechanism of the party system, internal party conflicts (for example, against the backdrop of conflicting positions concerning potential partnerships), the organization of political parties, random events that cannot be analysed objectively, the strength of minority governments and informal links such as external support provided to the government. ${ }^{15}$ Thus, in the strategic calculations of political parties, the interests are confronted with contextual constraints.

Previous studies in Western Europe based on rational choice theory, combined with an empirical approach to research into coalitions, have demonstrated certain rules associated with the motivations and constraints of coalition formation with the extreme right by mainstream right-wing parties. Research suggest that mainstream parties cooperate with the extreme right in the cabinet arena when they maximise the attainment of three goals simultaneously: participation in government, completion of own programme goals, and increase in electoral support. This is unique as parties usually face trade-offs between these goals when assuming office. As de Lange concludes: "Mainstream right parties in Western Europe prefer RRWPs [Radical Right-Wing Populists - authors explanation] to mainstream left parties as coalition partners because they are 'cheap' coalition partners which can easily be dominated and with which coalition agreements can be concluded without too many difficulties." ${ }^{16}$ Studies indicate that moderate right-wing parties take into account the size of the extreme party in their coalition

13 A. Antoszewski, Tworzenie i utrzymanie koalicji gabinetowych, in: A. Antoszewski, R. Herbut (eds.), Demokracje zachodnioeuropejskie. Analiza porównawcza, Wrocław 2007, pp. 306-309.

14 A. Antoszewski, Koalicje gabinetowe $w$ Europie, in: W. Bokajło (ed.), Studia z teorii polityki, kultury politycznej i myśli politycznej, Wrocław 1996, p. 60.

15 A. Antoszewski, Tworzenie $i$ utrzymanie koalicji..., p. 308; M. Laver, N. Schofield, op. cit., pp. 195-211; W.M. Lanny, T.S. Randolph, Government Formation in Parliamentary Democracies, “American Journal of Political Science” 2001, Vol. 45, Issue 1, pp. 33-38.

16 S.L. De Lange, Radical Right, p. 194. 
calculations (how many votes they received in the elections and seats in parliament). There is a tendency to enter into coalitions with larger parties or those whose support is growing, which makes it possible to form a majority coalition on the right. ${ }^{17}$ Twist slightly corrects this view by adding that the size of the extreme right-wing party is not important, but rather how important the party (its number of seats) is for the creation of a majority coalition. ${ }^{18}$ On programme issues, research has shown that the distance between parties is important for a coalition with the extreme right. Van Spanje argues that the smaller the distance between the moderate and extreme right, the less likely ostracism from the right-wing mainstream parties is. ${ }^{19} \mathrm{De}$ Lange points out that the extreme right is invited to join a coalition when the distance between moderate and extreme right-wing parties is smaller. ${ }^{20}$ She also points out that proximity in socio-cultural issues is the most important predictor of the participation of extreme right-wing parties in the governing coalitions in Western Europe. De Lange argues that this is a result of logrolling. ${ }^{21}$ Twist stresses, however, that the moderate right forms a coalition with extreme parties when these parties agree on programme issues that are crucial for mainstream parties at the moment. ${ }^{22}$

Research results have also shown that the extreme right is seen by the mainstream parties not only as an ally, but also as a competitor. The coalition is therefore often part of a long-term strategy of vote seeking or, in other words, a strategy of neutralising the electoral success of the extreme parties. ${ }^{23}$ Researchers have found that one

17 T. Bale, op. cit., p. 70; J. Van Spanje, Parties beyond the Pale: Why some Political Parties are Ostracized by their Competitors while Others are not, "Comparative European Politics" 2010, Vol. 8, Issue 3, pp. 354-383.

18 K.A. Twist, op. cit., p. 11.

19 J. Van Spanje, op. cit.

20 S.L. De Lange, From Pariah to Power, J. Van Spanje, op. cit.

21 S.L. De Lange, From Pariah to Power, S.L. De Lange, New Alliances: Why Mainstream Parties Govern with Radical Right-Wing Populist Parties, "Political Studies" 2012, Vol. 60, Issue 4, pp. 899-918.

22 K.A. Twist, op. cit., pp. 19-22.

23 R. Heinisch, Success in Opposition-Failure in Government: Explaining the Performance of Right-Wing Populist Parties in Public Office, "West European Politics" 2003, Vol. 26, Issue 3, pp. 91-130; S.L. De Lange, New Alliances...; B.M. Meguid, Competition Between Unequals: The Role of Mainstream Party Strategy in Niche Party Success, "American Political Science Review" 2005, Vol. 99, Issue 3, pp. 347-359; B.M. Meguid, Party Competition between Unequals, Cambridge 2008; B. Pytlas, O. Kossack, Lighting the Fuse: the Impact of Radical Right Parties on Party Competition in Central and Eastern Europe, in: M. Minkenberg (ed.), Transforming the Transformation? The East European Radical Right in the Political Process, London 2015; B. Pytlas, Radical Right Parties in Central and Eastern Europe. Mainstream Party Competition and Electoral Fortune, London 2016; M. Minkenberg, The Radical Right 
of the possibilities for mainstream parties to compete with the extreme right parties is co-opting policy issues in order to win over their supporters. This strategy can be adopted by a party before the elections, but also in the process of forming a coalition. By inviting an ideologically close party into government, mainstream parties may seek to discredit it as a ruling power, while at the same time fulfilling some of its demands so as to regain the electorate lost in previous elections in future elections. Moreover, having operated so far in the political margins, an extreme right party that becomes part of the establishment softens its criticism of political elites - thus giving up its most powerful weapon in its fight to mobilize voters. By inviting the extreme right to join the coalition, the moderate right-wing parties can thus achieve the short-term objectives of policy- and office-seeking and long-term vote-seeking, which in other coalition constellations are often mutually exclusive. ${ }^{24}$

Research also indicated specific changes in the Western European party system that have enabled coalitions between mainstream right and extreme right parties. An electoral shift to the right has taken place along with the increase of support for extreme right parties. This has changed the balance of power in European parliaments. Increasing support for extreme right parties has encouraged mainstream parties to move to the right on cultural issues like immigration, integration and security in order to win back voters. This has caused the convergence of party positions on the right and thus polarization of the party system (among other things, increased distance between mainstream right and left parties). This situation gives the mainstream right parties the rationale for cooperation with the extreme right. ${ }^{25}$

Among other factors determining coalitions with the extreme right in Western Europe, those that limited the possibility of forming a coalition with such parties are particularly interesting for the analysis of the coalition concluded in Poland in 2006. De Lange points to the so-called behavioural constrains, which parties impose on themselves. An example is the situation when parties have a priori defined (usually before elections) visions of who they do and do not want to cooperate with in government. Then, groups not included in

in Public Office: Agenda-Setting and Policy Effects, "West European Politics" 2001, Vol. 24, Issue 4, pp. 1-21.

${ }^{24}$ This strategy was adopted by right-wing parties in many Western European countries. The result of this strategy was, among other things, the electoral and organisational weakening of the extreme right-wing parties after participation in the government.

25 T. Bale, op. cit.; S.L. De Lange, From Pariah to Power, pp. 212-214. 
the coalition plan have little chance to govern. Many extreme right-wing parties became subjects of so-called anti-pacts, i.e. they were a priori excluded as a potential coalition partner, e.g. the Italian Social Movement (MSI) and Vlaams Blok (VB). ${ }^{26}$ However, anti-pacts may also pose a risk for moderate right-wing parties. They limit their ability to react flexibly by, for example, assuming part of the extreme right-wing agenda and ideological convergence. Such action could be considered a betrayal of the anti-pact and the party would then bear the electoral costs. On the other hand, the anti-pact could turn out to be unpopular among the voters of the moderate party, which could result in support for the extreme right in the next elections. ${ }^{27}$ Twist also points to the limitations stemming from the concerns of the moderate right about the stability of coalitions with the extreme right, which may be due to divisions within the mainstream party or instability among extreme right-wing parties. One example is ÖVP, which in 1986 and 1995 did not form a coalition with FPÖ because of strong internal opposition. The leaders of ÖVP were afraid of a rebellion by MPs, the loss of the ruling majority and a split in the party. Another reason was that the objectives of ÖVP (Austria's entry into the EC), which were important at the time, were incompatible with the Eurosceptic attitude of the FPÖ. The divisions and conflicts among the extreme right-wing parties - between FPÖ and BZÖ - were the reasons for not forming a coalition with the extreme right in 2006 and 2008. A similar situation occurred in the case of the failure to re-establish a coalition with LPF in 2003 in the Netherlands. ${ }^{28}$

26 The parties excluded a priori usually have too few seats, which is necessary to form a majority government with moderate right-wing parties, or they are distant in ideological and programmatic terms, making compromise impossible, see: K.A. Twist, op. cit., p. 136; S.L. De Lange, From Pariah to Power, p. 221.

27 S.L. De Lange, From Pariah to Power, p. 221-222.

28 A.K. Twist, op. cit., p. 136. A rupture between those favoring the rational option, who wish to take part in government, and fundamentalists, who oppose compromises, may concern not only the mainstream party but also members of the extreme parties. This may lead to the party's breakdown; the examples of the Austrian Freedom Party and the Swiss People's Party show that this is a very likely scenario, see: Cappocia G., Repression, Incorporation, Lustration, Education: How Democracies React to Their Enemies. Towards a Theoretical Framework for the Comparative Analysis of Defense of Democracy Repression, Paper presented to the ECPR Joint Sessions of Workshops, Grenoble, 6-11 April 2001, Workshop: Democracy and the New Extremist Challenge in Europe, pp. 25-26; W.M. Downs, Political Extremism in Democracies. Combating Intolerance, New York 2012, pp. 111-146. 


\section{THE WINDING ROAD TO COALITION WITH THE EXTREME RIGHT IN POLAND - INCENTIVES AND CONSTRAINTS}

OFFICE AND POLICY MOTIVATIONS - COALITION OPPORTUNITY STRUCTURE IN 2005/2006

The primary function of the formal coalition theories (office- and policy-seeking) is to predict governing coalitions following particular elections. By analysing events post factum we may determine what motivated parties to enter into a given coalition. The models also show the coalition opportunity structure for specific parties within the framework of the broad spectrum of potential cabinet coalitions.

Consistent with the rationality paradigm, coalition formation theories are based on the assumption that political parties are utility maximisers. Office-oriented coalition formation theories assume that parties seek to maximize their share of spoils: their primary goal is to gain office. This led scholars to expect minimal winning coalitions that controlled a majority in parliament but carried no additional, unnecessary partners that do not contribute to the winning status of the coalition. Thus, the parties do not have to share the prize (benefits) with too many other actors. Since the number of potential coalitions predicted by minimal winning theory is very large, it only gives an indication of which coalitions might be formed. This general theory has been refined to limit the number of potential predictions. In addition, two other theories have been developed: minimum size theory and bargaining theory. Minimum size theory predicts the formation of the minimal winning coalition with the smallest weight. It is based on the assumption that the payoff is proportional to the amount of resources (seats). Therefore, a party will achieve greater payoffs the greater its weight in the coalition by maintaining the minimal total coalition weight. However, the bargaining proposition predicts that the minimal winning coalition with the smallest number of parties will form. Thus it also takes into account the ease with which a coalition can be constructed, and maintains that a party forming government should seek to minimize the number of parties in the coalition, all other things being equal. Policy-seeking theories assume that parties seek to maximize their influence over policy making, and that politicians are motivated by policy goals alongside or instead of the simple desire to get into office. The minimal connected winning 
theory predicts that parties in a coalition will try to maximize policy coherence to minimize conflicts of interest, thus reducing transaction costs. This theory predicts the formation of coalitions with parties connected (adjacent) on a policy scale. Such coalitions can include unnecessary actors located in between the necessary actors located at the extremes. It may also contain members that make the predicted coalition oversized but are necessary to keep it connected. Another variant of this idea is that parties will form the minimal winning coalition with the smallest ideological range (least ideological diversity) as measured by the distance between the two members of the coalition that are the furthest apart on a policy scale - the minimal range theory. However, the minimal rage theory assumes that if it is also connected (closed variation), policy considerations take priority for a party over office. The open version does not stipulate that the coalition has to be connected, thus office considerations override policy concerns. ${ }^{29}$

The purpose of this analysis is not to test the theory of coalition, but to use it as a tool to understand the conditions and approximate the potential motivations for entering into a coalition with the extreme right in Poland after the 2005 elections. In order to use the above described logical and mathematical models, it is necessary to rely on quantitative data. The analysis of the Polish case is based on data from the 1999-2010 Chapel Hill Expert Survey. The data from Chapel Hill seems to be particularly useful as it represents party distance on two dimensions - economic Left/Right (LRECON) and socio-cultural (GAL/TAN). ${ }^{30}$ The unique policy conditions of government cooperation with radical right identified in Western Europe indicate the necessity of analysing distance in both dimensions. However, it should be noted that the expert surveys do not precisely overlap with the 2005 election in Poland. The surveys were conducted in 2006, the year

29 S.L. De Lange, New Alliances..., pp. 902-903.

${ }^{30}$ On the economic left/right dimension, parties are classified in terms of their stance on economic issues. Parties on the economic left want government to play an active role in the economy. Parties on the economic right emphasize a reduced economic role for government: privatization, lower taxes, less regulation, less government spending, and a leaner welfare state. GAL/TAN means on the one side "Green, Alternative, Liberal" positions, which typically support more expansive personal freedoms - greater civil liberties, same-sex marriage and greater democratic participation. Conversely, parties on the "Traditional, Authoritarian, Nationalism" end of the spectrum typically reject these ideas, favoring instead law and order, tradition, stability, the belief that the government should be a strong moral authority on social and cultural issues, see: A. Brigevich, B.W. Smith, R. Bakker, Unpacking the Social (GAL/TAN) Dimension of Party Politics: Euroscepticism and Party Positioning on Europe's "Other", Paper prepared for the 15th Biennial EUSA Conference, Miami FL, May 4-6, 2017; Codebook Chapel Hill Expert Survey-Trend File 1999, 2002, 2006, 2010. 
when the coalition with the extreme right was formed. This is why account should also be taken of the fact that the positions of parties (or the perception of those positions) at the moment of the survey, in comparison to the period in which elections were held, could have shifted in the examined ideological dimensions. Small changes may have occurred also in the number of seats held by parties in the parliament. ${ }^{31}$ This will be discussed in more detail in the following section.

Formal coalition formation theories indicate that within the context of potential coalition solutions that existed in Poland following the 2005 elections, the coalition with the extreme right was predicted under three theories - minimal winning, minimal connected winning and minimal range (closed version). Given that the government coalition commanded 245 seats (out of 460) and was comprised of three parties: the Prime Minister's party Law and Justice (PiS), the Self Defence of the Republic of Poland (SRP) and the League of Polish Families (LPR), this coalition was predicted neither by the minimum size theory nor by the bargaining proposition (see: Tables 1 and 2). Thus, the policy-oriented theories predicted the actual government perfectly, connected on both of the applied dimensions, Left/Right and Gal/Tan. Considering that the socio-cultural dimension is a mirror reflection of the economic dimension, SRP was the most left-leaning party and PiS the most right-leaning on the economic left-right dimension (see: Table 2). On the Gal/Tan dimension, SRP was also the most left-leaning party in the coalition and LPR the most right-leaning. The coalition with the extreme right (PiS-SRP-LPR) also had the lowest policy range on both dimensions: 0.83 on the Left/Right and 2.29 on the Gal/Tan. It should be also emphasised that LPR did not command enough seats to be the sole coalition partner for the mainstream right-wing PiS party. From the mathematical perspective Self-Defence of the Republic of Poland was the key party. LPR was a secondary coalition partner, complementary, but nevertheless vital in the formation of a majority government. The other coalition possibility, with similar properties - minimal winning, minimal connected winning, with the second smallest range, was Law and Justice-Self-Defence-Polish People's Party (PSL) (2.33 on the Left/Right and 4.43 on the Gal/Tan). This coalition was also slightly smaller in size than the one including LPR

${ }^{31}$ In 2005-2006, the total number of mandates for PiS-SRP-LPR decreased from 245 to 239 . 
(236 seats versus 245), thus it was also predicted by the minimum size theory. ${ }^{32}$

TABLE 1

Elections results to the Sejm in 2005

\begin{tabular}{|l|c|c|c|c|}
\hline \multirow{2}{*}{} & \multicolumn{2}{|c|}{$\%$ of votes } & \multicolumn{2}{c|}{ Number of seats } \\
\cline { 2 - 5 } & $\begin{array}{c}\text { Elections } \\
2005\end{array}$ & $\begin{array}{c}\text { Change since } \\
\text { last elections }\end{array}$ & $\begin{array}{c}\text { Elections } \\
2005\end{array}$ & $\begin{array}{c}\text { Change since } \\
\text { last elections }\end{array}$ \\
\hline Law and Justice & 26.99 & +17.49 & $\mathbf{1 5 5}$ & +111 \\
\hline Civic Platform & 24.11 & +11.43 & 133 & +68 \\
\hline $\begin{array}{l}\text { Self-Defence of the Republic } \\
\text { of Poland }\end{array}$ & 11.41 & +1.21 & $\mathbf{5 6}$ & +3 \\
\hline Democratic Left Alliance & 11.31 & -29.73 & 55 & -162 \\
\hline League of Polish Families & 7.97 & +0.10 & $\mathbf{3 4}$ & -4 \\
\hline Polish People's Party & 6.96 & -2.02 & 25 & -17 \\
\hline Other & 11.22 & +1.49 & - & \\
\hline
\end{tabular}

Source: State Election Commission.

TABLE 2

The position of Polish political parties on the economic axis left-right and socio-cultural axis gal-tan in 2006 (on a scale of 0-10)

\begin{tabular}{|c|c|c|c|c|c|c|}
\hline 2006 & SRP & LPR & PiS & PSL & SLD & $\mathrm{PO}$ \\
\hline Econ. L-R & 1.17 & 1.17 & 2.0 & 3.5 & 4.67 & 8.17 \\
\hline 2006 & SLD & $\mathrm{PO}$ & PSL & SRP & PiS & LPR \\
\hline Gal/Tan & 1.57 & 2.71 & 5.14 & 7.71 & 9.57 & 10.00 \\
\hline
\end{tabular}

Source: 1999-2010 Chapel Hill Expert Survey, L. Hooghe et al. 2010.

The bargaining theory (possibility to form a two-party minimal winning coalition) predicted only one coalition - between the Prime Minister party Law and Justice and liberal Civic Platform (PO). However, its total weight would be significantly greater in comparison with the participation of either LPR (34 seats) or PSL ( 25 seats). The participation of an equal-size partner in the coalition (the difference in electoral support between PO and PiS was $2.88 \%$ of votes) would force the governing party to offer an equal share of ministries and

${ }^{32}$ This was due to the smaller number of seats won by PSL, 25, versus by LPR, 36, in the 2005 elections. 
other offices linked with the exercise of power. Furthermore, the distance between these parties in both of the analysed dimensions demonstrates - consistent with the theory - the initiating party's limited ability to realize the government's policies. Thus, according to the theory a "grand coalition" was of no benefit to the governing party.

The findings suggest that the formation of a governing coalition with the extreme right in Poland after elections in 2005 would maximize the prime minister party's influence over policy and the share of spoils. Thus, the question arises: why was the coalition formed nine months after the elections? In other words, what factors constrained the conclusion of this coalition? The formal theories of coalition formation applied in the preceding passages are unable to answer these questions; it is thus necessary to analyse additional factors like long-term vote-seeking motivation, the characteristics of the party system, and specifics of individual parties, particularly the structure of rivalry in the party system and internal party dynamics and conflicts.

THE STRUCTURE OF INTER-PARTY COMPETITION AND 2005 ELECTIONS

Taking into consideration the dimensions of political and electoral rivalry in Poland, we may distinguish two periods: 1989-2005 and 2005(7)-present. During the former period, the primary demarcation line in the rivalry ran between the post-communist parties on one side, which were the Left Democratic Alliance (SLD) and its allies the Polish People's Party (PSL), and numerous groups derived from the anti-communist Solidarity camp on the other side. Apart from these, another set of parties existed which did not identify with either of the above-described camps including the extreme right and populist League of Polish Families and the agrarian-populist Self-Defence.

In contrast to the stable democracies of Western Europe, the debate over settling accounts with the communist past was more important (decommunization, vetting), as well as over abortion and the position and the role of the Catholic Church in the state, than distinctions between various policies for many years after the collapse of communist regime. This had its consequences: firstly, it muddied the distinctions between left and right, which were long associated in Poland with attitudes towards the past and socio-cultural issues rather than the traditional left-right economic divide; secondly, basing politics on symbols and values served to radicalise political rivalry; thirdly, this division was also reflected at the cabinet level as so-called regime divide, typical for many post-communist 
states. ${ }^{33}$ Until 2007 , post-solidarity parties had not cooperated with post-communist ones. These were the so called "anti-pacts" - declarations that a coalition will not be formed with post-communist formations. ${ }^{34}$ "Thus, political pedigree rather than programmatic similarities was the decisive factor at the root of coalition strategies. ${ }^{35}$ At the same time the "anti-pacts" were never aimed at any radical-right party in Poland." ${ }^{36}$

By accenting a common heritage and a desire to combat the political pathologies uncovered in the Third Polish Republic during the governments of the post-communist SLD, the mainstream right-wing parties Civic Platform (PO) and Law and Justice (PiS) announced in 2004, a year before the elections, their intention to form a governing coalition - the so-called POPiS. Paradoxically, the closer the elections came, the greater was the discord between the future partners. Regardless of how eagerly both of the parties were seeking to engage in a final reckoning with the post-communist left (mainly SLD), they were pushed into direct confrontation in the face of the left's weakness taking the cudgel against each other with increasing frequency while continuing to declare their intention to govern together. ${ }^{37}$

Because both groups appealed to rightist values and emerged from the Solidarity camp, their confrontation was based chiefly on issues of economics (the "solidary and social" option championed by PiS versus the "liberal" option offered by $\mathrm{PO}$ ), and concerned the state's role in the life of society. Thus in the 2005 elections, the significance of the axiological dimension of political rivalry was matched by that of the economic cleavage. It should be emphasized that this radical shift

${ }_{33}$ T. Szawiel, Podział na lewice i prawice $w$ Polsce po 1989 roku-jego sens $i$ trwałość, in: R. Markowski (ed.), System partyjny i zachowania wyborcze, Warszawa 2002.

${ }^{34}$ An exception was the decision taken by Law and Justice in 2002 in which a governing coalition with SRP was excluded. Politicians of PiS felt that a government with their participation could not include members with convictions in cases involving indictable offences, and A. Lepper had several convictions against him.

35 A. Antoszewski, J. Kozierska, Poland: Weak Coalitions and Small Party Suicide in Government, in: T. Bergman, G. Ilonszki, W.C. Müller (eds), Coalition Governance in Central Eastern Europe, forthcoming, Oxford 2019, p. 383.

${ }^{36}$ A fact demonstrated by the coalition formed in 1997 between the right-wing "Solidarity" Electoral Action (AWS) and the liberal Freedom Union (UW). The composition of AWS included several small radical right groups, such as the National-Democratic Party and the National Right.

37 A. Antoszewski, Wybory parlamentarne 2005 i ich konsekwencje dla rozwoju polskiego systemu partyjnego, in: D. Waniek (ed.), Partie polityczne $w$ wyborach 2005, Warszawa 2006 , pp. 80-83. This tendency was reinforced by the fact that it would be the first occasion since the political transformation that both parliamentary and presidential elections were held at the same time (with a two-week gap between voting). As a result, the strategies of the parties were different from in previous elections, and the campaign itself was exceptional, M. Cześnik, M. Kotranowski, Nowy wymiar politycznego współzawodnictwa: Polska Solidarna versus Polska Liberalna, "Studia Polityczne" 2011, No. 27, p. 130. 
in discourse was initiated by PiS, which re-framed the campaign as a choice between the vision of Civic Platform, which would benefit society's "winners," and the more egalitarian concept of PiS in the interests of those who felt that they had lost out. At the same time national values, moral absolutism, tradition and the family found themselves at the centre of Law and Justice's identity in the run-up to the 2005 elections. ${ }^{38}$ With time, PiS shifted further toward the right end of the socio-cultural axis (see: Graph 1). The party co-opted the national-Catholic and anti-elite rhetoric of LPR, which led later (in the 2007 elections) to the capture of a portion of that party's electorate and some of its members as well. Thus, the initial differences between PiS and PO grew during the campaign and especially after the election in the socio-cultural sphere and regarding the reform of the Third Republic. With time, PO distanced itself from radicalism, fashioning itself into a rational force attempting to remain at the centre of the political spectrum. ${ }^{39}$ However PO's shift toward the left-liberal (Gal) end at the time of the 2005 election campaign was not yet evident.

\section{GRAPH 1}

Changes in the positions of political parties on the GAL/TAN socio-cultural axis and Left-Right economic axis in 2002-2006 (scale of 0-10)

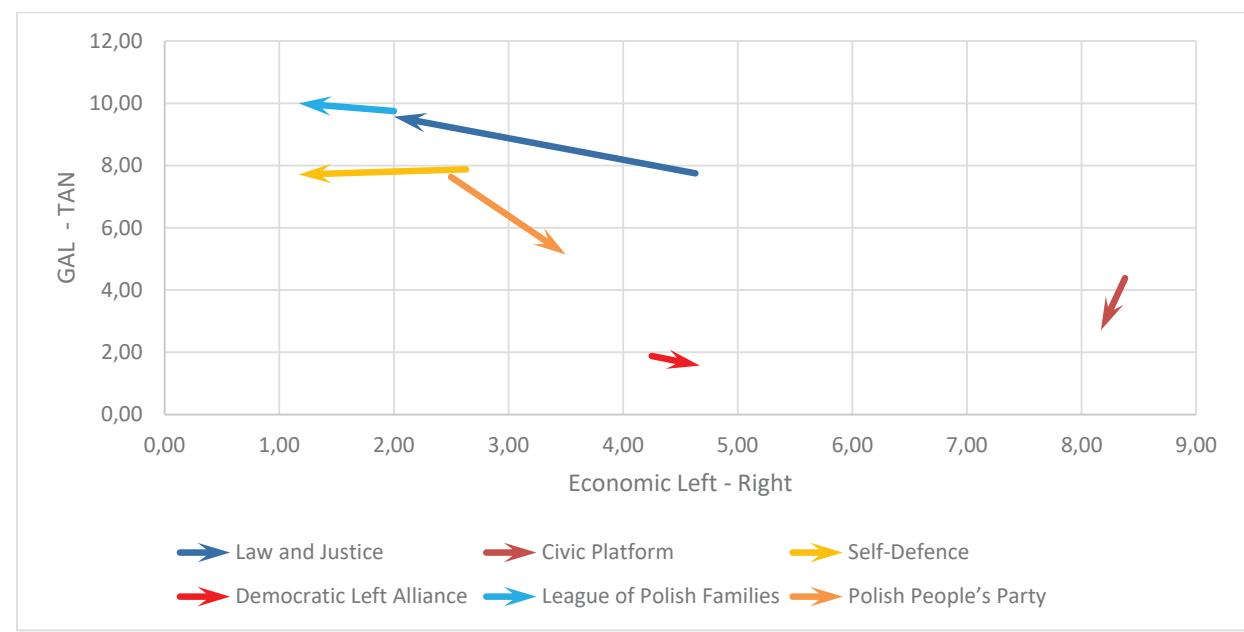

Source: Own elaboration based on 2002-2006 Chapel Hill Expert Survey L. Hooghe et al. 2010 .

38 R. Pankowski, The Populist Radical Right in Poland: the Patriots, London-New York 2010, pp. 235-238.

39 A. Lipiński, Delegitymizacja III Rzeczypospolitej. Budowanie partyjnej tożsamości i dyskursywne struktury możliwości, „Studia Polityczne” 2012, No. 4, p. 84-89. 
The models of cooperation and rivalry among the remaining parties in the party system did not undergo significant change in the period 2002-2006. Although the Left Democratic Alliance (after 15 years of transformation) became the primary representative of Polish social democracy, it remained isolated in 2005 because of its post-communist roots. It positioned itself on the centre-left on the economic dimension and on the far left on the socio-cultural axis. The other post-communist formation, PSL, succeeded in rebuilding its pre-war peasant party identity. However, Christian values, patriotism and elements of socialism placed the party at the centre or centre-right of the political spectrum. This allowed PSL to potentially enter into coalitions with actors on both the left and right sides of the political spectrum. ${ }^{40}$ Nevertheless, considering its communist roots the party served for years as the primary coalition partner for SLD (despite significant differences in socio-cultural issues). In spite of visible differences SRP was the main competitor for PSL. The parties were competing for the rural and small-town electorate, particularly of an agricultural character. Self-Defence may be considered an agrarian populist party, but with an eclectic ideology, whose anti-elite rhetoric was based primarily on social and economic postulates. Additionally, SRP displayed elements associated with the radical right, such as xenophobia and a kind of "social conservatism." 41 Thus, SPR was placed at the far left on the economic axis and on the centre-right on the GAL-TAN dimension. Finally, the League of Polish Families was placed at the farthest right end of the Polish political spectrum following the 2001 elections. As its identity was primarily defined by cultural nationalism and fundamentalist Catholicism, it took a typically radical-right rejectionist standpoint towards liberalism and European integration; xenophobic attitudes and even anti-Semitism also emerged. Like the Western European populist radical-right parties, LPR offered a populist critique of democracy, pitting itself against elites. Also characteristically for the populist radical right its economic stance was a mélange of liberal and egalitarian-interventionist slogans. Although strong pro-social policy stances and economic chauvinism (protecting domestic entrepreneurship from foreign capital) place the party on the extreme left of the

\footnotetext{
40 W. Sokół, M. Żmigrodzki, Współczesne partie i systemy partyjne: zagadnienia teorii i praktyki politycznej, Lublin 2011.

${ }^{41}$ A. Moroska, K. Zuba, Two Faces of Polish Populism. The Causes of the Success and Fall of Self Defense and the League of Polish Families, "Totalitarismus und Demokratie" 2010, Vol. 7, pp. 128-133.
} 
economic axis, LPR can be labelled as a "soft right-wing extremism" or radical right-wing populism. In 2005, both LPR and SRP described themselves as the only possible alternative to the post-communists and liberals, to the "Round Table" order. However, LPR made the fight against corruption and bad government its priority. In this respect it was close to the mainstream right-wing party PiS. Both parties pushed the most uncompromising positions on the functioning and repair of democracy in Poland expressed in the slogan of building the "Fourth Republic," and the vision of a pro-social Poland. ${ }^{42}$

Law and Justice was victorious at the ballot box (see: Table 1). In elections to the lower house of parliament (Sejm) PiS had a $2.88 \%$ advantage over PO, but that lead was much greater in the upper house (Senate) and in presidential voting. ${ }^{43}$ The nearly $30 \%$ loss of votes borne by SLD in relation to the preceding elections sidelined that group politically. The resulting situation, in which two large parties were left to confront each other, did nothing to benefit the small parties operating on the peripheries of the parliamentary scene. Self-Defence improved its return by only $1.21 \%$, but, in spite of this, managed to emerge as the relative victors by occupying third place in the parliament, making the party an important player in coalition negotiations. PSL had reason to be disappointed after losing over $2 \%$ of their voters, as did LPR, which, while its proportion of votes improved marginally (by $0.10 \%$ ), in fact lost tens of thousands of voters and four seats in parliament.

In summary, the consequences of the 2005 elections were a significant shift of the electorate to the right, which resulted from both a shift to the right at the individual level ${ }^{44}$ as well as electoral absenteeism among left-leaning voters, a polarization of the right side of the political scene, convergence of party positions of the mainstream right-wing party Law and Justice, and extreme-right League of Polish Families. While the post-communist cleavage lost its importance, while a new one appeared between "solidary Poland"

42 However, in 2006, just prior to officially entering government, LPR's new program indicated a visible moderation of party positions, see: A. Moroska, Prawicowy populizm a eurosceptycyzm: na przykładzie Listy Pima Fortuyna $w$ Holandii $i$ Ligi Polskich Rodzin $w$ Polsce, Wrocław 2010, pp. 237--268.

43 PiS controlled nearly half of the seats in the Senate (49 of 100). In presidential elections Lech Kaczyński defeated Donald Tusk by $8 \%$ of votes (54.04\% to $45.96 \%)$.

44 According to data from the Polish General Election Study (PGSW), the average for Polish society on an 11-point L-R scale in 2001 was 4.66, while in 2005 it was 6.07; for those casting a ballot it was 4.66 and 6.32 respectively, M. Cześnik, M. Kotranowski, op. cit., p. 133. 
and "liberal Poland." Thus, a fundamental step in the evolution of the structure of inter-party competition occurred, which also had consequences for the creation of a coalition involving the radical right. A side effect of the left's fall was a reorientation in socio-political discourse towards the interests of the right side of the spectrum. The two leading right-wing parties (PO and PiS) indicating the pathological nature of the principles governing the Third Republic at the same time delegitimized the political order. Through anti-communism as well as appeals to Christian and national values, they created conditions for the diffusion of ideas applied liberally by the Polish extreme right already before 2005 elections. ${ }^{45}$

\section{LONG-TERM VOTE-SEEKING MOTIVATIONS}

The formation of government is inevitably intertwined with electoral competition. Vote-related explanations are based on the assumption that prime minister parties seek to minimize their electoral losses and maximise their gains through the selection of junior coalition members. According to Dawns, "Future-conscious politicians are constrained by the need to compete for the electorate's favours in order to attain or retain office. This necessity should increase the likelihood that representatives will prefer to appear reliable and consistent to the electorate by adopting a 'clean hands' strategy of disengaging from the pariah." ${ }^{\prime 6}$ However, electoral gains made by radical right parties may also reflect public preferences. Moreover, parties focus on electoral changes in the party system and past or future electoral prospects, which inform their identification of electoral competitors and, in turn their vote-seeking strategies. Thus, the inclusion of radical-right parties in government could be seen as, for example, an opportunity to neutralize the competition for the prime minister party, even though the short-term office and policy-seeking and long-term vote seeking behaviour are likely to conflict.

In accordance with the pre-election coalition "pact," the two largest political parties entered into coalition negotiations shortly after elections to Sejm in 2005. However, the first talks revealed significant differences in the parties' visions for construction of the "Fourth Republic," an idea broadly supported by both parties.

45 A. Lipiński (2012), op. cit., pp. 78-83. In the autumn of 2005, 52\% of respondents agreed with the statement that non-democratic governments can sometimes be more desirable than democratic governments; in comparison to 2000-2004, this represented a rise of 10-15\%, CBOS, Stosunek Polaków do demokracji, Komunikat z badań, BS/194/2005.

46 S.L. De Lange, From Pariah to Power, p. 123. 
Successive elements of the eventual contract proposed by PiS proved unacceptable to the defeated PO. ${ }^{47}$ In the end, PO withdrew from talks, and President Kwaśniewski appointed the Marcinkiewicz government on 31 October, composed entirely of ministers from PiS or not affiliated with any party. Both parties traded accusations as to who was responsible for the disastrous result of coalition talks. Public opinion polls indicate that $44 \%$ of PiS voters and $78 \%$ of PO voters supported the "grand coalition." At the same time, a significantly smaller percentage of PiS voters opted for a government including Self-Defence and LPR or PSL (21\%), or for a minority government $(18 \%) .{ }^{48}$ Not without significance is the fact that support at that time for PiS was on an upward trajectory, in November reaching its highest point of $43 \%$. This was made possible by the fact that the majority of the PiS electorate (54\%) regarded PO as responsible for the collapse of coalition negotiations. ${ }^{49}$ In that situation, PiS could risk governing alone with the support of SRP, LPR and PSL, avoiding the necessity of giving up offices to junior coalition members. Furthermore, the creation of a minority government did not directly break the promise of cooperation with PO. Party leader Kaczyński continued to give the impression of being open to a potential coalition with the PO. In doing so, he was also attempting to mitigate the potential disappointment of voters and enhance the legitimacy of his own actions. It was, however, highly unlikely that the parliament's entire term of office would be seen out, something PiS must have understood. This allowed for the suspicion that the party was playing for time so as to lay the groundwork in society for the early dissolution of parliament and assumption of government independently, or for entry into a coalition with SRP and LPR or PSL without the necessity of conducting early elections.

In successive months support for PiS remained relatively high at around $32-39 \%$, yet there were noticeable indications that PiS had reached the upper limits of electoral expansion and began to lose

47 This concerned the offer from PiS that PO would receive half of the government's 16 ministries, but none of them included the so-called power ministries (interior, justice, secret services). The leaders of PO spoke openly of their fears that the power of state authority would be abused by PiS, and of a situation that "(...) PiS will govern, and PO will carry out the orders of PiS." PiS also rejected the candidates proposed by PO for the positions of Marshal of the Sejm and the Senate, A. Dudek, Historia polityczna Polski 1989-2012, Kraków 2013, p. 544.

${ }^{48}$ CBOS, O niedoszłej $i$ ewentualnych koalicjach rzadowych, Komunikat $z$ badań, $\mathrm{BS} / 190 / 2005$.

49 Ibidem. 
voters to the benefit of its rivals, primarily PO. ${ }^{50}$ During the same period, support for other groups, save for PO, dropped significantly. In January 2006, Self-Defence enjoyed support at a level of 4-7\%, while LPR registered $5-6 \%$, and PSL could count on $1-2 \%$ support (below the threshold for entry into parliament). ${ }^{51}$ In this situation, assuming early parliamentary elections, PiS could expect significant gains in electoral support, although it was doubtful whether the party could assume total control of government. The elimination of smaller parties and strengthening of $\mathrm{PO}$ would reinforce the bi-polar structure of the Polish parliament, which would render the dominating party scenario unrealistic and force PiS to enter into a partnership coalition with PO. ${ }^{52}$

Thus, in the face of growing problems with maintaining stable support for its minority government, PiS decided to enter into a "stability pact" with SRP and LPR, and later to form a coalition with these parties. ${ }^{53}$ However, it should be emphasized that PiS frequently indicated an alternative possibility: early elections, a threat which it had successfully used to apply pressure to smaller potential allies. In the face of continuing conflicts with SRP and LPR, Jarosław Kaczyński finally proposed holding early elections, but only SLD supported this idea. It is doubtful that PiS did, in fact, wish to resign from government when considering that the party's leaders did not exhaust all of the constitutional possibilities for initiating the dissolution of the Sejm. ${ }^{54}$

The high support for PiS provided it with a strong mandate to retain power at all costs. PiS could even suppose that in April 2006, after many months of cooperating with LPR and SRP in supporting the PiS minority government, those voters who had not come to accept its cooperation with the populists no longer supported the party. Moreover, the motivation of PiS to enter into a coalition with LPR

50 Support for Civic Platform fluctuated between 25\% and 33\%, approaching nearly the same level of support for PiS (35\%), PO (33\%) at the end of January 2006, TNS OBOP, Preferencje partyjne Polaków w maju 2006 r., Warszawa, May 2006, No. K.031/06.

51 Ibidem.

52 M. Gulczyński (2006), Charakterystyka głównych sił politycznych uczestniczacych w wyborach 2005, in: D. Waniek (ed.), Partie polityczne w wyborach 2005, Warszawa 2006 , p. 48-51.

53 The Stability Pact was an agreement providing for joint work in the Sejm and support for 144 draft bills.

54 Constitutional possibilities in Poland for shortening parliament's term of office and holding early elections exist in the form of an Act on the disbanding of parliament $(2 / 3$ majority required), or resulting from the disbanding of the government following exhaustion of the so-called three steps, see: Art. 98, 154 and 155 of the Constitution of the Republic of Poland. 
could well have been the desire to neutralize it. Analysis of support of "second votes" indicates that LPR and Self-Defence constituted (apart from PO) potential rivals to PiS. Nonetheless, only $10 \%$ of the PiS electorate would have voted for LPR as their second party, while as much as 35\% of the LPR electorate would have voted for the prime minister party. ${ }^{55}$ The LPR's loss of a significant share of voters before entry into the coalition may have benefited PiS, but the party could still enter parliament in future elections and constitute a potential rival on the right side of PiS. Furthermore, the participation of populists in the government gave PiS the opportunity to lay blame at the feet of coalition partners for its potential (and very likely, considering the problems arising in the course of the stability pact) collapse. This would enable the prime minister party to minimize the electoral costs of being the ruling party.

In summary, the risk of losing electoral support as a result of entering into an unpopular coalition with an extreme-right populist party reduced as time passed. At the same time, it seemed very probable that PiS could successfully acquire LPR's voters as well as SRP in future elections.

\section{INTRAPARTY DYNAMICS}

Roman Giertych, the leader of LPR, proposed cabinet cooperation with Law and Justice just after the elections. LPR's support for the minority government of the Law and Justice party would be given in exchange for promises of implementing a portion of his party's programme, such as the withdrawal of the Polish army from Iraq or renegotiation of the EU accession treaty. At that time, however, PiS did not betray any interest in cooperating with LPR, as evidenced by the words of one of the leaders of PiS, Ludwik Dorn: "LPR is entirely beyond the scope of our interest."56 At the same time, the PiS candidate for president Lech Kaczyński announced that the party had absolutely no plans of forming a governing coalition with Self-Defence or LPR. ${ }^{57}$ Jarosław Kaczyński also repeatedly ruled out the possibility

55 Self-Defence was also a rival for PiS, exhibiting an essentially equal capacity for gains and losses. Around $12 \%$ of the electorates of both parties indicated one of the two, CBOS, Układ poparcia dla partii politycznych przed wyborami do parlamentu, Komunikat $\mathrm{z}$ badań, BS/100/2005.

56 A. Dudek, op. cit., p. 539.

57 PAP, L. Kaczyński: PiS nie ma planów koalicji z Samoobrona czy LPR, October 7, 2005, https://www.pb.pl/1-kaczynski-pis-nie-ma-planow-koalicji-z-samoobrona-czy-lpr-281009. 
of cooperation with the SRP and LPR, defining the groups as radicals and populists: "(...) we cannot allow the group of the excluded or those who fear change to grow. If such a large group were to meet at the ballot box, we would have the governments of radical and populist parties Self-Defence, League of Polish Families or post-communists." 58

However, faced with the ultimate failure of talks with PO, Jarosław Kaczyński accepted the offer from SRP and LPR of support for a PiS minority government in exchange for implementing a portion of their postulates (LPR demanded pro-family and economic projects). Yet, cooperation with extreme parties became the subject of extensive controversy and a source of division within the leadership of PiS. An example came with the vote of the Political Committee of the Law and Justice party on the issue of the decision to sign the "stabilization pact" with SRP and LPR, which was adopted by a vote of 11 to 8 . Those opposing included the PM Kazimierz Marcinkiewicz, Ludwik Dorn and Krzysztof Putra, who voiced support for early elections, while the party's leader Jarosław Kaczyński, Marek Jurek and Kazimierz Ujazdowski were in favour of the pact. ${ }^{59}$ The rift was also a product of personal conflicts within the party. Evidence suggests that in the face of Marcinkiewicz's high popularity, Kaczyński feared for his position in the party, which in the event of early elections could be definitively buried. ${ }^{60}$ The proposal to dissolve the Sejm submitted by the Law and Justice party can therefore be seen as a justification for Jarosław Kaczyński to enter into a coalition with Self-Defence and LPR. As a result of the lack of support for early elections, J. Kaczyński steered the leadership of PiS to adopt a resolution authorizing him to enter into coalition talks. As a result, the Minister of Foreign Affairs Stefan Meller resigned from government. ${ }^{61}$ The internal opposition and the possible risk of a split in PiS could have been a factor inhibiting the decision to enter into a coalition with LPR and SRP, although it was not ruled out completely.

The formation of the coalition was preceded by a split in the League of Polish Families between ideologists accusing the Law and Justice party of acting contrary to the programme assumptions and

58 Interview with Jarosław Kaczyński, February 14, 2005, http://www.batory. org.pl/programy_operacyjne/debaty/cykl_naprawa/artykuly_15/wyklad_jaroslawa_ kaczynskiego_14_lutego_2005 [access: February 15, 2005]; A. Dudek, op. cit., p. 548.

59 „Gazeta Wyborcza”, February 8, 2006.

60 "From October 2005 to June 2006 support for PM Marcinkiewicz rose from 59\% do $74 \%$, while for J. Kaczyński it fell from 60\% to 34\%. A. Dudek, op. cit., p. 553.

${ }^{61}$ Interia Fakty, September 22, 2006, https://fakty.interia.pl/news-piec-miesiecykoalicji-pis-samoobrona-lpr,nId,812150 [access: September 23, 2006]. 
pragmatists seeking to take up positions in the government. ${ }^{62}$ The reason for LPR refusing to enter government was, consistent with party documents, PiS's abandonment of the "national-socialist program" agreed to in the stabilization pact, as well as a lack of partnership in relations between the coalition partners. However, facing the threat of collapse, party leader Giertych decided to finally join forces with the Law and Justice party. This, together with the lack of trust and conflicts accompanying the cooperation in parliament between Law and Justice and LPR, as well as SRP, did not give rise to the formation of a stable government and hope for survival of the term of office. Nevertheless, faced with the alternative of early elections, especially after PSL definitively refused to join the coalition, the Law and Justice Party decided to cooperate with SRP and LPR, justifying it on the one hand by the possibility of implementing planned reforms, while on the other hand by advancing the image of the coalition as a by-product of legislative mathematics, highlighting the purely instrumental character of the coalition.

\section{CONCLUSIONS}

The main objective of this paper was to explain the participation of the extreme right party (LPR) in the Polish government in 2006. More precisely, the aim was to define the motivations of the mainstream right-wing party for collaborating with the extreme right populists in the executive arena, and also to indicate the potential reasons why the coalition was not formed until nine months after elections. Thus, there is also the question of what constraints existed on the construction of this coalition. The analysis involved the application of theories of coalition formation, based on the rational choice paradigm combined with an empirical approach to research into coalitions. This approach made it possible to identify numerous regularities in the formation of coalitions with the extreme right in Western Europe, whose results served as a source of inspiration and a starting point for the present analysis. The aim of the analysis was also therefore to indicate whether the motivations for establishing a coalition with the extreme right in Poland were based on similar premises and mechanisms as in Western Europe.

${ }^{62}$ In April, a group of LPR MPs who joined the coalition agreement with PiS withdrew from the party. 
From the perspective of rational choice theory, the analysed case has revealed that the coalition with the extreme right was the most beneficial one for the prime minister party in respect of policy and office goals. The coalition allowed PiS to maximize the number of offices held because LPR was the second smallest party in parliament (however, the difference to the smallest, PSL, was a mere nine mandates). ${ }^{63} \mathrm{At}$ the same time, LPR was a necessary partner from the mathematical point of view to build a majority coalition, especially after PSL refused to cooperate. According to formal theories of coalition formation, the motivation of this coalition was particularly inspired by policy considerations, as the ideological distance between the moderate and extreme right wing at that time was the smallest among all the parties represented in the Polish Sejm. According to the theory, this provided the dominant party with an optimal opportunity to achieve its political goals. Interestingly, this proximity was present both on the traditional economic axis and in socio-cultural issues. The analysis of the Polish case thus points to different policy-related explanations compared to the results of studies in Western Europe, where closeness between the moderate and extreme right-wing was only found in socio-cultural issues. This difference may have been result, among other things, from the ideological specificity of political parties in post-communist countries, especially the pro-social character of the conservative party in Poland. This issue undoubtedly requires further research on examples of coalitions with the extreme right in Central and Eastern Europe. The analysis also showed that the coalition with the extreme right was initially risky for the prime minister party in the electoral sphere. With time, the risk of losing voters decreased, and through co-optation of many of the ideological features of LPR, PiS could count on taking over a part of voters of the smaller coalition partner in the next elections. It seems, therefore, that vote-seeking motivations were a factor hindering cooperation with the extreme right-wing in Poland, and which delayed the formation of coalition with LPR. At the same time, these results confirm the conclusions of research in Western Europe, namely that right-wing mainstream parties enter into a coalition with the extreme right when they simultaneously maximise short-term office and policy goals as well as long-term voting goals.

The Polish case also revealed more general truths identified in Western European states, in particular concerning changes in the

\footnotetext{
${ }^{63}$ According to the results of elections to the Sejm in 2005.
} 
party system that have enabled coalitions with extreme right parties: the electoral shift to the right, polarization in the party system and convergence of ideological positions between mainstream right-wing and extreme right parties. This demonstrates the universality of certain mechanisms. On the other hand, the study also showed that the differences in many characteristics of the party system in Western and Eastern Europe matter. The regime divide typical for post-communist states for many years affected patterns of political rivalry and cooperation in Poland, and ultimately impacted government formation. The so-called anti-pact directed against the post-communists was one of the reasons for the pre-electoral coalition pact between the mainstream right parties PO and PiS. However, change in patterns of competition in the party system and polarisation between the main right-wing parties during the electoral campaign in 2005 altered the coalition opportunity structure in favour of smaller parties, including LPR. The coalition agreement, concluded before the elections, therefore became an inconvenience, and significantly constrained the possibility of concluding a coalition with the extreme right just after the elections. Thus, indirectly, regime divide had an impact on coalition scenarios in Poland and contributed to the postponement of the coalition with the extreme right. An interesting aspect undoubtedly worthy of further research is how the divisions typical of post-communist countries influenced the possibility of forming a coalition with the extreme right in other countries of Central and Eastern Europe.

This Polish case study also shows that the conclusion of a coalition with the extreme right was influenced by internal party dynamics. Both in the case of Law and Justice and LPR, the resistance of party elites became a factor hindering cooperation and the formation of a coalition between parties. In the case of PiS, strong opposition among party leaders to a coalition with LPR and SRP, including from Prime Minister Marcinkiewicz, should be mentioned. Additionally the rivalry for dominance in the party between two leaders - Jarosław Kaczyński and Marcinkiewicz, also of significance for the strategic coalition activities taken by PiS. Internal divisions were also important for LPR, whose leader, as a result of months of problematic cooperation with PiS, objected to joining the coalition. Faced with the alternative of early elections, and the very likely result of PiS going into opposition, Law and Justice tried at all costs to form a majority government by subjugating smaller coalition partners. Unlike in Austria in 2006 or 
the Netherlands in 2003, the risk of instability in a coalition based on pressure and mutual distrust did not become a factor excluding cooperation with the extreme right in Poland in 2006.

The PiS-SRP-LPR government turned out to be the most unstable government of the Polish Third Republic. As a result, early elections were held in October 2007 that brought an end to cooperation at the cabinet level with the extreme right. In consequence, PiS manged to eliminate the smaller coalition parties from the Polish political scene, and while itself failed to retain power, it gained voters, improving its result compared to 2005. The party succeeded in placing blame on its coalition partners for the government's failure, absorbed much of their political agenda, and took over a part of their electorates. ${ }^{64}$ At the same time, in the course of following decade, it eliminated its competition on the right.

The analysis of the Polish case demonstrates that the motivations of the right-wing mainstream party to join coalitions with the extreme right could result from rational calculations based on office, policy and vote motivations. At the same time, unforeseen events in the political environment and internal party dynamics had an impact on the change of coalition party strategies over time, including the postponement of the process of joining the coalition with the extreme right. The importance of potential motivating factors identified in the Polish case as well as those limiting the coalitions with the extreme right, i.e. the proximity of moderate and extreme right parties in various ideological dimensions, the indirect regime divide effect on the coalition with the extreme right and internal party dynamics undoubtedly require further research exploring examples of extreme right-wing coalitions in Central and Eastern Europe.

\section{BIBLIOGRAPHY}

Albertazzi D., Mueller S., Populism and Liberal Democracy: Populists in Government in Austria, Italy, Poland and Switzerland, "Government and Opposition" 2013, Vol. 48, Special Issue 03.

Antoszewski A., Koalicje gabinetowe w Europie, in: W. Bokajło (ed.), Studia $z$ teorii polityki, kultury politycznej i myśli politycznej, Wrocław 1996. Antoszewski A., Kozierska J., Poland: Weak Coalitions and Small Party Suicide in Government, in: T. Bergman, G. Ilonszki, W.C. Müller (eds),

${ }^{64}$ Every fourth SRP voter and every second LPR voter in 2005 supported PiS in the 2007 elections. R. Markowski, M. Cześnik, Wybory parlamentarne 2007 roku-Ciagły zamęt czy utrwalenie nowego rozłamu?, „Studia Polityczne” 2007, No. 27, p. 118. 
Coalition Governance in Central Eastern Europe, forthcoming, Oxford 2019.

Antoszewski A., Tworzenie $i$ utrzymanie koalicji gabinetowych, in: A. Antoszewski, R. Herbut (eds), Demokracje zachodnioeuropejskie. Analiza porównawcza, Wrocław 2007.

Antoszewski A., Wybory parlamentarne $2005 i$ ich konsekwencje dla rozwoju polskiego systemu partyjnego, in: D. Waniek (ed.), Partie polityczne w wyborach 2005, Warszawa 2006.

Axelrod R., Conflict of Interest: A Theory of Divergent Goals within Applications to Politics, Chicago 1970.

Bale T., Cinderella and Her Ugly Sisters: the Mainstream and Extreme Right in Europe's Bipolarizing Party Systems, "West European Politics" 2003, Vol. 26, Issue 3.

Brigevich A., Smith B.W., Bakker R., Unpacking the Social (GAL/TAN) Dimension of Party Politics: Euroscepticism and Party Positioning on Europe's "Other", Paper prepared for the 15th Biennial EUSA Conference, Miami, FL, May 4-6, 2017.

Cappocia G., Repression, Incorporation, Lustration, Education: How Democracies React to Their Enemies. Towards a Theoretical Framework for the Comparative Analysis of Defense of Democracy Repression, Paper presented to the ECPR Joint Sessions of Workshops, Grenoble, 6-11 April 2001, Workshop: Democracy and the New Extremist Challenge in Europe.

CBOS, O niedoszłej $i$ ewentualnych koalicjach rzadowych, Komunikat $z$ badań, BS/190/2005.

CBOS, Stosunek Polaków do demokracji, Komunikat z badań, BS/194/ 2005.

CBOS, Układ poparcia dla partii politycznych przed wyborami do parlamentu, Komunikat $z$ badan, BS/100/2005.

Cześnik M., Kotranowski M., Nowy wymiar politycznego współzawodnictwa: Polska Solidarna versus Polska Liberalna, „Studia Polityczne” 2011, No. 27.

De Lange S.L., From Pariah to Power: The Government Participation of Radical Right-Wing Populist Parties in West European Democracies, University of Antwerp, Antwerp 2008.

De Lange S.L., New Alliances: Why Mainstream Parties Govern with Radical Right-Wing Populist Parties, "Political Studies" 2012, Vol. 60, Issue 4.

De Lange S.L., Radical Right - Wing Populist Parties in Office - A Cross - National Comparison, in: U. Backes, P. Moreau (eds), The Extreme Right in Europe: Current Trends and Perspectives, Göttingen 2011.

De Swaan A., Coalition Theories and Cabinet Formations: A Study of Formal Theories of Coalition Formation Applied to Nine European Parliaments after 1918, Amsterdam 1973. 
Downs W.M., Pariahs in their Midst: Belgian and Norwegian Parties React to Extremist Threats., "West European Politics" 2001, Vol. 24, Issue 3.

Downs W.M., Political Extremism in Democracies. Combating Intolerance, New York 2012.

Dudek A., Historia polityczna Polski 1989-2012, Kraków 2013.

Gulczyński M., Charakterystykagłównych siłpolitycznych uczestniczacych w wyborach 2005, in: D. Waniek (ed.), Partie polityczne w wyborach 2005, Warszawa 2006.

Heinisch R., Success in Opposition-Failure in Government: Explaining the Performance of Right-Wing Populist Parties in Public Office, "West European Politics" 2003, Vol. 26, Issue 3.

Interia Fakty, September 22, 2006, https://fakty.interia.pl/news-piecmiesiecy-koalicji-pis-samoobrona-lpr,nId,812150 [access: September 23, 2006].

Interview with Jarosław Kaczyński, February 14, 2005, http://www. batory.org.pl/programy_operacyjne/debaty/cykl_naprawa/artykuly_ 15/wyklad_jaroslawa_kaczynskiego_14_lutego_2005 [access: February $15,2005]$.

Lanny W.M., Randolph T.S., Government Formation in Parliamentary Democracies, “American Journal of Political Science” 2001, Vol. 45, Issue 1.

Laver M., Schofield N., Multiparty Government. The Politics of Coalition in Europe, Michigan 2007.

Leiserson M., Coalition Government in Japan, in: S. Groennings, E.W. Kelly, M. Leiserson (eds), The Study of Coalition Behavior: Theoretical Perspectives and Cases from Four Continents, Holt, Rinehart and Winston, New York 1970.

Leiserson M., Coalitions in Politics: A Theoretical and Empirical Study, PhD Dissertation, Yale University, New Haven 1966.

Lipiński A., Delegitymizacja III Rzeczypospolitej. Budowanie partyjnej tożsamości $i$ dyskursywne struktury możliwości, „Studia Polityczne” 2012, No. 4.

Markowski R., Cześnik M., Wybory parlamentarne 2007 roku - Ciagły zamęt czy utrwalenie nowego rozłamu?, „Studia Polityczne” 2007, No. 27.

Meguid B.M., Competition Between Unequals: The Role of Mainstream Party Strategy in Niche Party Success, "American Political Science Review" 2005, Vo1. 99, Issue 3.

Meguid B.M., Party Competition between Unequals, Cambridge University Press, Cambridge 2008.

Minkenberg M., Profiles, Patterns, Processes: Studying the Eastern European Radical Right in its Political Environment, in: M. Minkenberg (ed.), Transforming the Transformation? The East European Radical Right in the Political Process, New York 2015. 
Minkenberg M., The Radical Right in Public Office: Agenda-Setting and Policy Effects, "West European Politics" 2001, Vol. 24, Issue 4.

Moroska A., Prawicowy populizm a eurosceptycyzm: na przykładzie Listy Pima Fortuyna $w$ Holandii i Ligi Polskich Rodzin $w$ Polsce, Wrocław 2010.

Moroska A., Zuba K., Two Faces of Polish Populism. The Causes of the Success and Fall of Self Defense and the League of Polish Families, "Totalitarismus und Demokratie" 2010, Vol. 7.

Pankowski R., The Populist Radical Right in Poland: the Patriots, London-New York 2010.

PAP, L. Kaczyński: PiS nie ma planów koalicji z Samoobrona czy LPR, October 7, 2005, https://www.pb.pl/1-kaczynski-pis-nie-ma-planowkoalicji-z-samoobrona-czy-lpr-281009 [access: October 23, 2019].

Pytlas B., Kossack O., Lighting the Fuse: the Impact of Radical Right Parties on Party Competition in Central and Eastern Europe, in: M. Minkenberg (ed.), Transforming the Transformation? The East European Radical Right in the Political Process, Routledge, London 2015.

Pytlas B., Radical Right Parties in Central and Eastern Europe. Mainstream Party Competition and Electoral Fortune, Routledge, London 2016.

Riker W.H., The Theory of Political Coalitions, Yale University Press, New Haven CT 1962.

Sokół W., Żmigrodzki M., Współczesne partie i systemy partyjne: zagadnienia teorii i praktyki politycznej, Lublin 2011.

Strom K.A., Behavioral Theory of Competitive Political Parties, "American Journal of Political Science" 1990, Vol. 34, Issue 2.

Szawiel T., Podzial na lewice i prawice $w$ Polsce po 1989 roku-jego sens $i$ trwałość, in: R. Markowski (ed.), System partyjny i zachowania wyborcze, Warszawa 2002.

TNS OBOP, Preferencje partyjne Polaków w maju 2006 r., Warsaw, May 2006, No. K.031/06.

Twist K.A., The Mainstream Right, the Far Right, and Coalition Formation in Western Europe, A dissertation University of California, Berkeley 2015.

Van Spanje J., Parties beyond the Pale: Why some political parties are ostracized by their competitors while others are not, "Comparative European Politics" 2010, Vol. 8, Issue 3.

Von Neumann L., Morgenstern O., Theory and Games of Economic Behavior, Princeton University Press, Princeton 1944; Gamson W.A., A Theory of Coalition Formation, "American Sociological Review" 1961, Vol. 26, Issue 3. 